\title{
ON THE STRATEGY OF SUSTAINABLE DEVELOPMENT OF RURAL AREAS OF THE RUSSIAN FEDERATION FOR THE PERIOD TILL 2030
}

\author{
R.Yanbykh
}

The Strategy of sustainable development of rural areas of the Russian Federation for the period till 2030 released in February 2015 should have determined the guidelines and mechanisms of rural areas' development in the country. However, instead of a manual for action with clearly defined priority measures and sources of their financing there appeared yet another formal document made of "good intentions".

The release of the Strategy of sustainable development of rural areas of the Russian Federation for the period till 2030 (RF Government Decree No-151-r of February 2, 2015) in February 2015 cannot fail to inspire both experts and the public. But has the Strategy given answers to questions that are the most burning for rural residents?

Question No.1: do we want the number of people living in rural areas to stabilize and if so, are we able to provide rural residents with decent employment and incomes? At the moment rural population of Russia amounts to 37.1 million or $26 \%$ of the country's total. The able-bodied population comprises 21.4 million rural residents or $57.6 \%$ of their total number. In the recent 15 years the size of rural population stabilized basically due to the migration inflow and some positive trends in the birth-mortality ratio (Fig. 1).

There are 153.1 thousand settlements in rural areas; of them 133.7 thousand have permanent residents. The number of inhabitants in $73 \%$ of rural settlements is less than 200 persons while the share of settlements with over 2,000 inhabitants is only $2 \%$ of their total number. $80 \%$ of municipal units are rural settlements. They constitute the major form of territorial organization of local government in Russia ${ }^{1}$.

The Strategy regards the current situation as optimal and sets the 2030 target indicator of rural population's share in the Russia's total at the currently observed level of $26 \%$ without any explanation. The strategy fully omits the issues of resettlement. The problem is just indicated when enumerating the existing types of rural areas: (I) with primarily agrarian specialization, favourable natural and social conditions; (II) with poly-functional rural economy, agriculture of suburban type and favourable social conditions for rural area development; (III) with unfavourable social conditions for rural area development and extensive socially and economically depressed areas; (IV) with poor spot development of rural areas

1 Report on sustainable development of rural areas. RF Ministry of Agriculture, 2014.

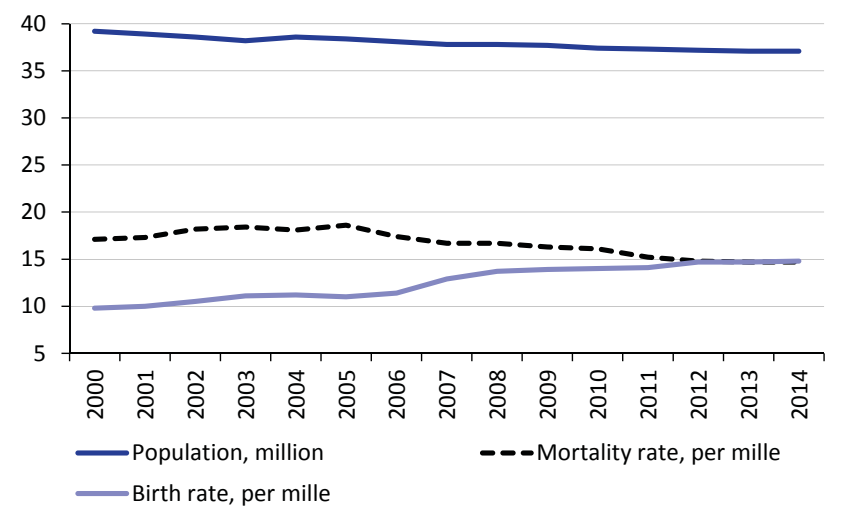

Source: Rosstat.

Fig. 1. Rural population: basic demographic trends

and unfavourable natural and climatic conditions ${ }^{2}$. Authors try to suggest a universal set of methods (such as diversification of rural economy, improvement of social and communal infrastructure, special demographic policy for depopulated territories) able to reverse the negative trends but do not clearly define which of the rural areas should be "rescued" and which should not ${ }^{3}$.

For instance, the ongoing debates about the development of Far-East region by means of granting land titles to Russian citizens and Ukrainian refugees have not been reflected in the Strategy, which is regretful. In its time the Stolypin reform started with similar steps: in 1906-1913 the population of the region increased by $153 \%$, sown areas - by $80 \%^{4}$. Nowadays, the FarEast Federal District occupying $36 \%$ of the country's territory and being the home for $5 \%$ of its population is the least populated area. The granting of land plots

2 Strategy of sustainable development of rural areas of the Russian Federation for the period till 2030.

3 Conservation of the existing settlement system may in some cases lead to the stagnation of areas. See: Yanbykh R. O kontseptsii ustoychivogo razvitiya sel'skhikh territoriy [On the concept of sustainable development of rural areas]. "Economic and political situation in Russia". 2011, No.1, p.p. 47-50.

4 Gektar kak stimul [Hectare as an incentive]. "Ogonyok", No. 3 of January 26, 2015. 
for all kinds of business could really foster diversification of rural economy in the region.

In Russia rural development measures are financed under the Federal Target Program "Sustainable development of rural areas in 2014-2017 and the period till 2020 " that is a component part of the State program for agricultural development and regulation of agricultural, input and food markets in 2013-2020. There are six basic directions for funds appropriation (Fig. 2):

- improvement of housing conditions for people living in rural areas including young families and young specialists;

- development of infrastructure (gasification, water supply, electric networks and telecommunications);

- development of medical, physical culture and sports network;

- development of secondary education, culture and leisure network;

- support of complex compact development of rural settlements;

- other, including fire protection, grant support of local initiatives of rural communities for the improvement of living conditions, encouragement and extension of accomplishments in rural development.

It's not hard to notice that the lion's share of $\mathrm{Rb} 299.2 \mathrm{bn}$ (of them $\mathrm{Rb} 99.7 \mathrm{bn}$ from the federal budget) to be appropriated within 8 years under the Federal Target Program "Sustainable development of rural areas in 2014-2017 and the period till 2020" will be spent on the construction of dwellings, gas and water pipelines and on the implementation of other measures for improving the quality of rural social and communal infrastructure. The European Union practices another approach: measures for supporting rural development are first of all targeted at farm restructuring and modernization (34\% of allocated funds), ecological activities and environmental protection, diversification of rural population's incomes (altogether $44 \%)$. One also supports the so called community initiatives $(6 \%$, an analogue of the Russian measure that, however, has never got funding despite being planned due to the annual curtailment of allocations). Over a comparable period (2007-2013) expenditures on these measures from the European Agricultural Fund for Rural Development (EAFRD) amounted to $96 \mathrm{bn}$ euro. A rough estimate reveals that from all sources of funding sustainable rural development an average rural resident in Russia can get 19 euro per year while a European - 117 euro. However, as noted above the directions of spending this money differ a lot. In our country still dominates the point of view that an accent in rural development should be made

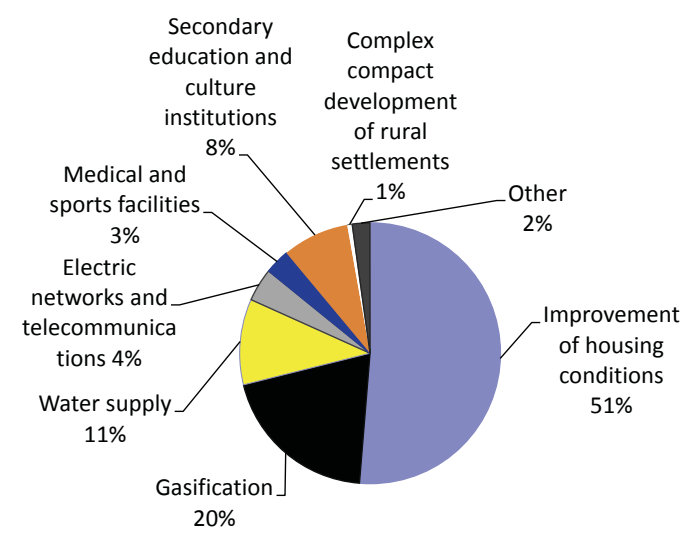

Source: Federal Target Program "Sustainable development of rural areas in 2014--2017 and the period till 2020".

Fig. 2. Financing of measures

for the sustainable development of rural areas

on improving rural infrastructure. It's clear that this task is extremely complicated given the vast territory of Russia. Therefore, we find that the directions of support should be to a greater extent defined by rural residents themselves while the funds should be distributed, for instance, through competition of infrastructural projects and other rural initiatives.

Target indicators of both the Strategy and the Federal Target Program "Sustainable development of rural areas in 2014-2017 and the period till 2020" deserve a special mentioning. Everything continues to be measured in the number of hospital beds, length of water pipelines and square meters per capita (Table 1) while not a single qualitative parameter is applied.

In Great Britain there is an interesting experience of transfer from exclusively quantitative per capita parameters to qualitative service standards ${ }^{1}$. The British Government assumes the responsibility for supporting quality standards of services provided to rural residents. It's enshrined in the common document of the Ministry of Agriculture, Fishery and Food ${ }^{2}$ and the Ministry of Environment, Transport and Regions dating back to 2000. This document named "Rural White Paper" $^{\prime \prime}$ is signed by the First Vice Prime Minister of the British Government. In case services fail to comply with quality standards any rural resident of Great Britain may apply to the court. Each year the standards are revised by the Government.

The following examples of guaranteed quality standards can be cited:

1. Local authorities responsible for education should provide for free transportation of a pupil

1 Rural Service Standard.

2 In 2002 the Ministry of Agriculture, Fishery and Food was reorganized into the Department for Environment, Food and Rural Affairs - DEFRA.

3 The full name of the document is "Our countryside: the future. A fair deal for rural England». 
BASIC INDICATORS OF FEDERAL TARGET PROGRAM “SUSTAINABLE DEVELOPMENT OF RURAL AREAS IN 2014-2017 AND THE PERIOD TILL 2020"

\begin{tabular}{|c|c|c|c|c|c|c|c|}
\hline & 2014 & 2015 & 2016 & 2017 & 2018 & 2019 & 2020 \\
\hline $\begin{array}{l}\text { Commissioning (acquisition) of dwellings for } \\
\text { citizens living in rural areas, } 1,000 \mathrm{~m} 2\end{array}$ & 838.1 & 368.3 & 305.6 & 395.5 & 434.8 & 478.4 & 524.9 \\
\hline $\begin{array}{l}\text { Commissioning of secondary educa- } \\
\text { tion institutions, } 1,000 \text { places }\end{array}$ & 4.1 & 1 & 0.9 & 1.2 & 1.3 & 1.4 & 1.6 \\
\hline $\begin{array}{l}\text { Commissioning of first aid and obstetric stations and (or) } \\
\text { offices of general practitioners, number of institutions }\end{array}$ & 105 & 39 & 33 & 44 & 50 & 55 & 62 \\
\hline Commissioning of flat sports facilities, $1,000 \mathrm{~m} 2$ & 63.7 & 23.6 & 20 & 26.5 & 29.9 & 33.4 & 37.4 \\
\hline $\begin{array}{l}\text { Commissioning of culture and lei- } \\
\text { sure institutions, } 1,000 \text { places }\end{array}$ & - & - & 0.5 & 0.7 & 0.8 & 0.8 & 0.9 \\
\hline Commissioning of gas distribution networks, $1,000 \mathrm{~km}$ & 3 & 1 & 0.8 & 1.1 & 1.3 & 1.5 & 1.7 \\
\hline $\begin{array}{l}\text { Rate of gasification of residential dwellings (apart- } \\
\text { ments) with pipeline gas in rural areas, } \%\end{array}$ & 57.3 & 57.6 & 57.9 & 58.2 & 58.6 & 59.1 & 59.6 \\
\hline Commissioning of local water pipelines, 1,000 km & 2.3 & 0.7 & 0.6 & 0.7 & 0.8 & 0.9 & 1 \\
\hline Rate of rural population's supply with drinking water, \% & 60.2 & 60.4 & 60.6 & 60.8 & 61.1 & 61.3 & 61.7 \\
\hline $\begin{array}{l}\text { Number of settlements with implemented projects of } \\
\text { complex development of residential construction sites }\end{array}$ & 10 & 19 & 5 & 2 & 5 & 10 & 15 \\
\hline $\begin{array}{l}\text { Number of implemented local initiatives of } \\
\text { rural residents supported by grants }\end{array}$ & 72 & 58 & 51 & 67 & 73 & 81 & 88 \\
\hline $\begin{array}{l}\text { Commissioning of hard-surface general use motorways to } \\
\text { the nearest public facilities in rural settlements, } 1,000 \mathrm{~km}\end{array}$ & - & 0.68 & 0.68 & 0.72 & 0.73 & 0.72 & 0.72 \\
\hline
\end{tabular}

Source: Federal Target Program "Sustainable development of rural areas in 2014-2017 and the period till 2020".

to the nearest school in case the latter is located out of the reasonable walking distance $(2$ miles for children younger than 8 and 3 miles for children older than 8).

2. The share of rural population living within 10-minute walking distance to a bus stop with headway of 1 hour or less should increase from the current $37 \%$ to $50 \%$ in 2015.

3. Guaranteed access to the professional first aid within 24 hours and to a physician within 48 hours by the end of 2014. 100\% pre-arrangement of visit to a doctor and possibility to call a doctor in, including by e-mail.

4. Ambulance should arrive to category A emergency calls (danger to life) within 8 minutes in $75 \%$ of cases. All other categories of emergency call should be attended to within 14 minutes in urban areas and 19 minutes - in rural areas.

5. Police should respond to calls in rural areas within 15-20 minutes.

6. In case a job-seeker lives in a remote rural area, he is granted the right to register and re-register job applications by mail. An interview with employer may be arranged in the place of applicant's residence (in case the trip together with interview will take him more than 8 hours) at the account of employment centers' budget.

7. The list of all government services should be available to rural communities in electronic form. This implies that as far back as in 2005 in all sites of rural residents' living there was access to Internet to let them easily read government websites and provide feedback with their complaints and suggestions. The access is provided through information kiosks of local authorities.

Perhaps, only one standard - that of pupils' transportation by school buses - is observed in Russia and even then not completely as the routes are limited. Meantime, the efficiency of state support to rural areas' development under the State program is estimated exclusively by comparing the actually achieved indicators with the planned ones. For instance, if there were plans to build 1,000 square meters of dwellings in the Kostroma Region and actually 1,500 square meters were built, the implementation rate for this parameter is considered to be $150 \%$. By the per capita availability of dwellings in rural areas (a target indicator of the Strategy) the region is in one of the first places in Russia - 33 square meters. However, this level is conditioned by the great number of derelict dwellings still remaining on the balance sheet in depopulated villages.

Not many expert teams ${ }^{1}$ are currently working at complex appraisal of rural population's living standards reflecting social and economic situation in Russia's

1 See: Nauchno-metodicheskiye osnovy ustoychivogo razvitiya sel'skikh territoriy [Scientific and methodological basis for sustainable development of rural areas]. Ed. by S.O. Siptits, L.A. Ovchintseva. Federal Budget Scientific Institution named 
rural areas but such methodologies exist in the World Bank and the Organization for Economic Cooperation and Development (OECD). For instance, the OECD "Better life index" includes 11 components $^{1}$ : housing

after A.A. Nikonov. Moscow: Entsiklopediya rossiyskhikh dereven' [Encyclopedia of Russian villages]. 2015, 185 p.

1 Better life index: http://www.oecdbetterlifeindex.org/ru/ conditions, income, job, society, education, ecology, civil rights, health, satisfaction, safety, ratio of work and leisure. We believe that indicators of the Strategy and the State Program should be revised accordingly. Sustainable development of rural areas should be primarily associated with higher living standards and work conditions for rural residents. 